obtained from the oxidized fibres. The principles underlying the use of tetrakis (hydroxymethyl) phosphonium chloride in flame-proofing wool have been examined, and it has been found that presence of this substance enhances the ability of fibres to take a set in aqueous media.

In the Department of Colour Chemistry and Dyoing there were 48 undergraduate students in the eightieth (1958-59) and 45 in the eighty-first (1959 60) session, with 17 and 23, respectively, working for higher degrees. A study of the influence of the acetyl value of acetate rayon on the rate of dyeing and affinity of disperse dyes was completed. Work continued on the kinetic and thermodynamic aspects of the dyeing of acetate rayon with sulphated dyes and on the influence of the chemical constitution of non-ionic azo dyes on their affinity for cellulose. Other work has been concerned with the effect of benzyl alcohol and $n$-butyl alcohol on the absorption by wool of dyes containing metal and the chemistry of ketones related to mesobenzanthrone, particularly their behaviour towards substituting agents and their ability to undergo self-union in alkaline media with formation of vat dyes. An investigation of the status of sulphinic acids as substituting agents yielded some interesting and potentially useful sulphones and some new reactions, and provided an explanation of the course of several applications of sulphinic acids in organic chemistry. Work was completed on derivatives of 2-methylanthraquinone and 2-alkylquinizarins and the influence of the chemical constitution of non-ionic azo dyes on their affinity for cellulose. Lists of publications during the year are included in both reports.

\title{
THE BRITISH LEATHER MANUFACTURERS' RESEARCH ASSOCIATION
}

T THE annual report of the British Leather Manufacturers' Research Association for the year October 1960-September 1961 *, includes the reports of the Council and of the Director of Research, the latter including a list of publications, together with details of membership of the Council, its committees and of staff. Renewed attention was given to the problem of finding new outlets for leather and emphasis was placed in a report to the Council on the overwhelming importance of using the raw hides and skins to the best advantage.

The Director's report outlines the programme of research for 1961-62 and notes some features of the current year's work. In background research, work on the composition of skin proteins centred on the separation of collagenous and non-collagenous protein in acetic acid extracts of calf-skin. Investigations of the mechanical and elastic properties of collagen and leather have been extended to combinationtanned fibres, both semichrome and chrome re-tan. In studying the deterioration of leather by heat, moisture and perspiration it has been shown that exposure to dry heat or to high humidities at normal temperatures eauses little deterioration and that it is the combined action of heat and moisture which is deleterious, involving breakdown of polypeptide chains both by hydrolysis and an oxidative process involving loss of amino-acids.

* British Leather Manufacturers' Research Association. Annual Report, 1960-61. Pp. 58. (Egham: Surrey: British Leather Manufacturers' Research Association, 1961.)
Experiments in which sheep-skins were deliberately allowed to stale before using have shown that while staling reduced the quality of the skins, as judged by thinness, pits and holes and also the strength of the leather, it did not appear to lower rot-resistance. Examination of the effect of adding antiseptics to the salt used for curing sheep-skins indicated that processes within the control of the fellmonger or tanner have at least as big an effect. Progress in reducing the cost of unhairing by enzymes is reported through the demonstration that the enzyme liquor can be re-used several times. It has also been found that salt concentrations of 10 per cent or more reduce enzyme activity in de-woolling sheep-skins and a 2 per cent solution of enzyme is just as effective as a 20 per cent solution.

Other work has been concerned with control of the thickness of vegetable-tanned sole leather, vegetable tan sludges, laminated leathers and solvent-assisted dyeing, in which a technique was developed for topping suèdes by spraying by emulsifying in wator a solution of the pigment dyestuff in benzyl alcohol. More recently, anionic dyestuffs have been dissolved in a single-phase solvent system of water, isopropyl alcohol and benzyl alcohol and sprayed direct on to the leather. Work has been started on new impregnating finishes for upper leather and considerable progress made in waterproofing chrome upper leather with silicones. The outstanding problem remaining is to improve the retention of silicones by the leather over long periods of use.

\section{NEW DIRECTIONS IN PETROLEUM EXPLORATION, PRODUCTION AND TRANSPORTATION} W WITING in the November-December $1961_{\text {issue of the Battelle Technical Review published }}$ by the Battelle Memorial Institute, Columbus, Ohio, Dr. Frank C. Croxton propounds some novel, if not revolutionary, ideas for explorations of oil-pools, techniques for crude-oil production and transportation.
In the field of exploration location of future oil deposits envisages extensive use of gas surveys, microbiological indicators, radio-geochemical methods and advanced electronic instruments. The aim is development and use of geophysical methods of greater sensitivity and portability, thus utilizing more direct methods of oil-finding, especially in "vast 
new areas which are conceivably as rich as the rest of the world in oil reserves". In the realm of produc. tion, conventional drilling operations may well be superseded by processes designed to eliminate altogether the rig as we know it to-day; in this direction the author relies on the rapidly advancing knowledge of more efficient application of energy, for example, effects of high temperature, explosives, sound and supersonics. "Production research of the future will, therefore, give much attention to faster and more economical ways of making, in rock, holes a few inches in diameter, many thousands of feet long, and aimed with precision." This ideal implies removal of torsional and tensile stresses from the drill-string, replacing drill-heads by electrical currents, use of plasma techniques, and even underground nuclear explosions.

Thermal drive, that is, heating the underground crude-oil deposit, is forecast as a secondary recovery procedure, since at elevated temperatures viscosity would be reduced and thereby flow to wells accelerated. As a corollary to this the possibility of attaining cracking temperatures, "in situ vis-breaking operation of the crude", is seriously considered.

Two noteworthy advances in petroleum transportation are the flexible oil barge and the flexible pipeline. The former, made of nylon-reinforced rubber, is towed practically submerged to its destination, thereafter collapsed into a comparatively small package and shipped back to point of origin. Flexible pipe-line, of proved value in submarine transportation of oil during the Second World War and since, is destined to be of far greater importance in this connexion in the future. "It has not been given to previous generations to see an area of technology born, develop to maturity, and then experience a substantial evolution, all during a human lifetime." Such has indeed happened in the petroleum industry, and because of this Dr. Croxton's speculations in this paper cannot be dismissed lightly.

\title{
SYNTHESIS OF PROTEIN AND RIBOSOMES BY BACTERIA
}

\author{
By Dr. S. DAGLEY, Dr. A. E. WHITE and DR. D. G. WILD \\ Department of Biochemistry, University of Leeds \\ AND \\ DR. J. SYKES \\ Department of Biochemistry, University of Sheffield
}

\begin{abstract}
$\mathrm{T}$ HE antibiotic chloromycetin (chloramphenicol) inhibits protein synthesis in bacteria but allows synthesis of ribonucleic acid (RNA) to continue ${ }^{1}$. Although there is evidence for a type of RNA termed 'messenger'",3 which is rapidly synthesized and degraded in Escherichia coli, most bacterial RNA exists as ribosomes which are particles containing protein and stable RNA. This 'normal RNA' differs from that accumulated during chloromycetin inhibition: the latter may be rapidly degraded by the cells during a phase of recovery from the antibiotic and some of the bases or nucleosides may pass from the cells into the surrounding medium from whence they are reabsorbed when growth resumes ${ }^{4}$.

This contrast in stability has given rise to the view that 'chloromycetin RNA' is abnormal or nonfunctional despite the fact that its base composition is the same as that of normal RNA (ref. 5). It may be noted, however, that the kinetics of degradation are not those to be expected for a detoxication process by which useless or harmful material is ejected: that is, degradation does not begin some time after the new material has accumulated; instead, synthesis and degradation proceed simultaneously with the rate of the former initially greater, so that 'chloromycetin RNA' is observed in radiotracer experiments to be 'turning over' during the whole period of its accumulation ${ }^{5}$. There is, in fact, no direct experimental evidence that this RNA causes protein synthesis to cease; on the other hand, it has been shown that chloromycetin itself inhibits biochemical reactions preceding peptidebond synthesis, namely, those concerned with transfer of amino-acids from 'soluble RNA' to ribosomes ${ }^{6}$.
\end{abstract}

Our results, and those of other workers, are readily interpreted on the view that: (1) most of the RNA synthesized by bacteria is labile unless it combines with protein; (2) 'chloromycetin RNA' is exceptional only in so far as it occurs in particles with a lower ratio of protein : RNA than that normally found, one of the effects of the antibiotic being to favour their stabilization. Such particles may normally exist as precursors of ribosomes.

When the cell synthesizes protein at the normal rate only a few of them may exist at any given time since they would be removed by the completion of stable ribosome structures; and when protein synthesis is suppressed by chloromycetin they would also be rapidly degraded by enzymes unless combination with the antibiotic, in addition to combination with protein, could reduce the rate of breakdown. Horowitz, Lombard and Chargaff ${ }^{5}$ found that the RNA. accumulating early in chloromycetin treatment was more stable than that accumulating later: thus, a factor opposing breakdown, probably protein, appears to have been less readily available the longer protein synthesis was inhibited. In agreement with this view it has been shown that 'chloromycetin RNA' occurs in particles which have a lower ratio of protein : RNA than $50 S$ ribosomes and give rise to additional peaks in schlieren diagrams at $14-18 S^{7-9}$. We find that extracts of puromycin-treated cells also show additional peaks sedimenting at this speed on examination in the ultracentrifuge. Now puromycin appears to inhibit the same steps in protein synthesis as chloromycetin ${ }^{10}$, but in contrast the RNA which accumulates is 'stable ${ }^{11}$. Accordingly, the argument that 'chloromycotin RNA' is abnormal because it is labile is greatly weakened: the ribonucleoprotein. (RNP) particles which accumulate during inhibition by puromycin are similar physically to those from chloromycetin treatment, but they contain stable RNA. It is simpler to suggest that puromycin stabil- 